Agricultural Biochemistry and its Application

http:/www.journals.zu.edu.eg/journalDisplay.aspx?Journalld=1\&queryType=Master

\title{
GINGER ESSENTIAL OIL IN VITRO INHIBITS CELL GROWTH AND INDUCES APOPTOSIS IN MCF-7 HUMAN BREAST ADENOCARCINOMA CELLS
}

\author{
Atef A. Abd El-Rahman ${ }^{1}$, S.M.A. El-Shafei ${ }^{1}$, H.A. Elwan ${ }^{2}$ and F.K. Alimova ${ }^{3}$ \\ 1. Agric. Chem. Dept., Fac. Agric., Minia Univ., Egypt \\ 2. Anim. and Poult. Prod. Dept., Fac. Agric., Minia Univ., Egypt \\ 3. Biochem. and Biotechnol. Dept., Inst. Fundamental Med. and Biol., Kazan Federal Univ., \\ Kazan, Republic of Tatarstan, Russian Federation
}

Received: 15/10/2017 ; Accepted: 01/11/2017

\begin{abstract}
Ginger plant (Zingiber officinale) is known as one of the important medicinal plant and dietary substances that are rich in phytochemicals. It has been used as a food flavoring agent as well as for traditional oriental medicinal purposes for centuries. Therefore, this study aimed to evaluate the inhibition of growth and induction of apoptosis (in vitro) in breast cancer cell line (MCF7) using ginger essential oil (GEO). For this purpose, cells were exposed to $0,20,60$ and $100 \mu \mathrm{g} / \mathrm{ml}$ of GEO for $72 \mathrm{hr}$. Cell viability and cell proliferation were performed by using trypan blue and 3-(4,5dimethylthiazol-2yl)- 2,5-biphenyl tetrazolium bromide (MTT) assays. Cellular morphological changes were examined by phase contrast inverted microscopy. Furthermore, the mitochondrial transmembrane potential assay was evaluated by flow cytometry using tetramethylrhodamine, ethyl ester (TMRE) dye as an indicator of apoptosis. The results revealed that, human breast cancer cell line (MCF-7) was sensitive to the treatment with various GEO concentrations. Treatment of cells with GEO resulted in a reduction in cell viability, growth inhibition, distinct changes in cellular morphology and induction of apoptosis in a concentration dependent manner. The lowest percentage of viable cells was recorded as $20.68 \%$ at a concentration of $100 \mu \mathrm{g} / \mathrm{ml}$ of GEO. GEO was found to have cytotoxic activity against MCF-7 cells (in vitro) with an IC50 value of $10.12 \mu \mathrm{g} / \mathrm{ml}$ and induces apoptosis by loss of mitochondrial membrane potential $(\Delta \Psi \mathrm{m})$. Our findings demonstrate that, GEO inhibited MCF-7 proliferation by inducing apoptosis and may have applications in the field of anticancer drug development.
\end{abstract}

Key words: Ginger oil, apoptosis, MCF-7 cells, TMRE, breast cancer cells.

\section{INTRODUCTION}

In both developed and developing countries breast cancer is the most frequent cancer. It is the most common type of cancer and the second most common cause of cancer death among females in Asia, Western countries and others (Farshori et al., 2013). It is often referred to as one disease, but there are many types of breast cancer. Breast cancers can be divided into 2 major types, noninvasive (in situ carcinomas) and invasive (infiltrating) (Richie and Swanson, 2003). The first type may arise in either ductal or lobular epithelium, but remain confined there, with no invasion of the underlying basement membrane. The second type can start in the ducts or lobules, but then they spread into surrounding breast tissue (ACS, 2014). MCF-7 (human breast adenocarcinoma cell line) is a breast cancer cell line that was first isolated from a 69-year-old Caucasian American woman in 1970. It is the acronym of Michigan Cancer

\footnotetext{
* Corresponding author: Tel. : +201019695527

E-mail address: atefnagi2000@yahoo.com
} 
Foundation-7, referring to the institute in Detroit, USA where the cell line established in 1973 (Soule et al., 1973). Since then it has become a prominent model system for the study of breast cancer (Simstein et al., 2003; Hamedeyazdan et al., 2012).

From ancient times, it has been known that, some essential oils from medicinal plants possess antibacterial, antifungal and antioxidant properties (Dagli et al., 2015). Ginger is a rhizomatous plant grown in Asia, China, Japan, Austria, Latin America, and Africa (Sasidharan and Nirmala, 2010). Ginger extract contains numerous potent phytochemicals including gingerols, shogaols, zingerols, paradols and others (Jolad et al., 2004). Shogaols and gingerols are the principal active pharmacological components of ginger (Plengsuriyakarn et al., 2012). They have cytotoxic effects against lung, ovarian, and skin cancer cell lines (Kim et al., 2008). In the last several years, many researchers have extensively studied ginger oil as an anticancer agent and they found that, ginger oil exert potential effects against cancer, skin problems, gastrointestinal tract diseases, and central nervous system disorders associated with oxidative and inflammatory stresses (Sang et al., 2009; Dugasani et al., 2010 ; Kubra and Rao, 2012). Furthermore, [6]-shogaol as one of the major active components of ginger has been shown to exhibit anticancer activities against breast cancer (Ling et al., 2010), anti-proliferation activity, (Choudhury et al., 2010) and antiinvasion of human hepatocellular cell (Weng et al., 2010). To our knowledge, in the last few years, much current research has focused its attention to ginger given its anticancer and antiinflammatory activities (Karimi and Roshan, 2013; Mariadoss et al., 2013; Hakim et al., 2014; Wee et al., 2015 ; Jeena et al., 2016), but unfortunately, there has been little research on cytotoxic activity of ginger essential oil against MCF-7 human breast cancer cells (Yuangang et al., 2010). Our previous study has demonstrated a cytotoxic activity of fungal culture filtrates against MCF-7 cells (Abd El-Rahman et al., 2014). In the recent decades, there has been a growing interest in the use of essential oils in the pharmaceutical industries (Coisin et al., 2012), a systematic study of ginger oil has become very important. Therefore, this study aimed to evaluate the cytotoxic and apoptotic activities of GEO against MCF-7 human breast cancer cells.

\section{MATERIALS AND METHODS}

\section{Consumables and Chemicals}

Tissue culture plates and serological pipets were purchased from Biofil, Belgium. Commercially ginger oil was purchased from El-Captain Company, Cairo, Egypt. Penicillin streptomycin 10.000 units/ ml, L-glutamine 200 $\mathrm{mM}$, fetal bovine serum (FBS) and Dulbecco's Modified Eagle's Medium (DMEM) culture medium, were purchased from Gibco, Life Technologies, UK. Trypsin purchased from Serva, Heidelberg, Germany. All other specified reagents and solvents were purchased from Sigma Chemical Company Pvt. Ltd. St. Louis, MO, USA.

\section{Ginger Essential Oil Preparation}

Ginger essential oil was purchased from ElCaptain company, Cairo, Egypt. Ginger oil (1 $\mathrm{ml})$ dissolved in $1 \mathrm{ml}$ dimethyl sulfoxide (DMSO), the resulting solution was diluted with Dulbecco's Modified Eagle Medium (DMEM) 1: 100 and stored at $4^{0} \mathrm{C}$ until use.

\section{Cell Line and Culture}

Human breast adenocarcinoma cells (MCF-7) were obtained from research and education center pharma 2020, Kazan federal university, Russian federation. The cells were maintained in DMEM supplemented with $10 \%$ fetal bovine serum (FBS), $0.5 \%$ penicillin, streptomycin and $0.5 \%$ L-glutamine $200 \mathrm{mM}$ at $37^{\circ} \mathrm{C}$ in a $5 \% \mathrm{CO}_{2}$ atmosphere with $95 \%$ humidity (ESCO, CelCulture, $\mathrm{CO}_{2}$ incubator). Before beginning the experiments, viability of cells was assessed following the protocol of Siddiqui et al. (2008). MCF-7 cells showing more than $95 \%$ cell viability.

\section{Experimental Design}

Cells were plated in 96-well culture plates (5 $\times 10^{3}$ cells/well) followed by incubation at $37^{\circ} \mathrm{C}$ for 24 hours for attachment and then exposed to various concentrations of GEO $(0,20,60$ and $100 \mu \mathrm{g} / \mathrm{ml}$ ) for 24 hours to assess the cell viability assay by trypan blue dye, and cellular morphology by phase contrast inverted 
microscope. Cell proliferation and mitochondrial transmembrane potential assays were determined by using MTT and TMRE dyes after 24 and $72 \mathrm{hr}$., of incubation with GEO respectively.

\section{Trypan Blue-cell Viability Assay}

Cell viability of the treated and untreated MCF-7 cells was assessed using the trypan blue cell viability assay. Trypan blue is a widely used assay for staining dead cells. The cell viability assay was performed by adding $50 \mu 1$ of trypsinized cell suspension to $50 \mu 1$ of $0.4 \%$ trypan blue in a $500 \mu \mathrm{l}$ Eppendorf tube and gently mixed by pipetting up and down. The final solution was allowed to stand at room temperature for 2-3 min and cells were counted using the hemocytometer. The percentage of viable cells was calculated by the following formula:

Viable cells $(\%)=[1.00-($ Number of blue cells $\div$ Number of total cells) $] \times 100$.

\section{MTT-cell Proliferation Assay}

MCF-7 cell proliferation was determined by MTT assay (Mosmann, 1983). Cells were plated at a density of $5 \times 10^{3}$ cells per well in 96 well plates and incubated for $24 \mathrm{hr}$., at $37^{\circ} \mathrm{C}$ for attachment and then treated with various concentrations of GEO $(0,20,60$ and 100 $\mu \mathrm{g} / \mathrm{ml}$ ) followed by incubation at $37^{\circ} \mathrm{C}$ in $5 \%$ $\mathrm{CO}_{2}$ incubator for $72 \mathrm{hr}$. Cells treated with medium only served as a control group. After incubation for $72 \mathrm{hr}$., the supernatant was discarded and $10 \mu \mathrm{l}$ of MTT dye $\left(5 \mathrm{mg} \mathrm{ml}^{-1}\right.$ in PBS) with $90 \mu \mathrm{l}$ of medium was added to each well and incubated at $37^{\circ} \mathrm{C}$ for $4 \mathrm{hr}$. Then the purple-colored precipitates of formazan were dissolved by gently shaking for $10 \mathrm{~min}$ in dimethyl sulfoxide $(100 \mu \mathrm{l})$. After complete dissolution, the absorbance intensity measured by a microplate reader (TECAN Infinite M200, USA) at $555 \mathrm{~nm}$. The effect of GEO on growth inhibition was assessed as percent growth inhibition of cells and calculated according to Patel et al. (2009), using the following formula:

Cell inhibition $(\%)=100-[(\mathrm{At}-\mathrm{Ab}) \div(\mathrm{Ac}-\mathrm{Ab})] \times 100$

Where:
At $=$ Absorbance value of test compound; $\mathrm{Ab}=$ Absorbance value of blank; $A c=$ Absorbance value of control

Half-maximal inhibitory concentration $\left(\mathrm{IC}_{50}\right)$ values of test substances were calculated from at least three independent experiments using linear regression of the dose-log response curves by SOFTmaxPro.

\section{Morphological Changes}

Morphological changes in human breast adenocarcinoma cells (MCF-7) exposed to various concentrations of GEO were examined using a Zeiss Axio Vert. A1 microscope at 40X magnification. Treated cells were compared with control cells to can detect the morphological changes.

\section{Tmre-mitochondrial Transmembrane Potential Assay}

Loss of mitochondrial transmembrane potential was assessed by flow cytometry (Guava easycyte 8ht), using the fluorescent lipophilic cationic dye TMRE. TMRE dye is a red-orange dye, positively-charged, cell permeant that readily accumulates in active mitochondria due to their relative negative charge (Chazotte, 2011). TMRE accumulation in mitochondria is driven by $\Delta \Psi \mathrm{m}$; therefore, depolarization of $\Delta \Psi \mathrm{m}$ can be represented by the loss of TMRE staining (Akao et al., 2002). After treatment MCF-7 cells with $10.12 \mu \mathrm{g} / \mathrm{ml}$ of GEO (IC50) for $24 \mathrm{hr}$., cells were stained with $200 \mathrm{nM}$ TMRE for $20 \mathrm{~min}$ at $37^{\circ} \mathrm{C}$, then washed twice in medium and re-suspended in PBS. Some cells were incubated with $20 \mathrm{mM}$ carbonylcyanide-p-trifluoromethoxy phenylhydrazone (FCCP) for 10 minutes prior to staining with TMRE, served as a positive control for depolarized mitochondria. The TMRE fluorescence density was analyzed using (Guava easycyte $8 \mathrm{ht}$ ) flow cytometry. The data are presented as percentage of stained cells.

\section{Statistical Analysis}

Statistical analysis was conducted using the statistical analysis software SPSS (version 20). Data are expressed as mean \pm standard deviation (SD) of experiments each conducted in triplicate. Analysis of variance (ANOVA) was conducted to examine the differences between 
treatments followed by LSD multiple comparison test. P-value of $<0.05$ was considered to be statistically significant.

\section{RESULTS}

\section{Cell viability}

After $24 \mathrm{hr}$., of incubation with various concentrations of GEO $(0,20,60$ and $100 \mu \mathrm{g} /$ $\mathrm{ml}$ ), the percentage of MCF-7 viable cells was determined. The percent cell viability in MCF- 7 cells as observed by Trypan blue assay are presented in Fig. 1. Results showed that, GEO induced statistically significant $(p<0.05)$ decrease in the percentage of MCF-7 viable cells in a concentration dependent manner. MCF-7 cells exposed to $20 \mu \mathrm{g} / \mathrm{ml}$ and above concentrations of GEO for $24 \mathrm{hr}$., were found to be cytotoxic, and cell viability was found 95.2, 62.51, 25.12 and $20.68 \%$ at $0,20,60$ and $100 \mu \mathrm{g} / \mathrm{ml}$ of GEO respectively by Trypan blue assay (Fig. 1). Also, as the results showed that, the minimum percent of viable cells was $20.68 \%$ at a concentration of $100 \mu \mathrm{g} / \mathrm{ml}$ of GEO (Fig. 1).

\section{Cytotoxicity Screening}

Cytotoxicity of GEO was assessed using MTT assay. MCF-7 cells were exposed to GEO with various concentrations (20,60 and $100 \mu \mathrm{g} /$ $\mathrm{ml}$ ) and incubated for $72 \mathrm{hr}$. After incubation, the percent growth inhibition of cells and halfmaximal inhibitory concentration $\left(\mathrm{IC}_{50}\right)$ of GEO were determined. As shown in Table 1, the percent growth inhibition of MCF-7 cells treated with different concentrations of GEO $(20,60$ and $100 \mu \mathrm{g} / \mathrm{ml}$ ) for $72 \mathrm{hr}$., was recorded 85.5, 88.72 and $78.67 \%$, respectively using MTT assay (Table 1). The maximum and minimum percent inhibition of MCF-7 cells were 88.72 and $78.67 \%$ at a concentration of 60 and $100 \mu \mathrm{g} /$ $\mathrm{ml}$ of GEO, respectively. Furthermore, the $\mathrm{IC}_{50}$ value for MCF-7 cells was $10.12 \mu \mathrm{g} / \mathrm{ml}$ of GEO (Table 1).

\section{Morphological Alterations}

Changes in human breast adenocarcinoma cells (MCF-7) morphology were found to be concentration dependent manner. Morphological alterations observed in cells are shown in Fig. 2. Cells exposed to $20 \mu \mathrm{g} / \mathrm{ml}$ and above concentrations of GEO for $24 \mathrm{hr}$., reduced the normal morphology and cell adhesion capacity as compared to control (Fig. 2). MCF-7 cells exposed to 20,60 and $100 \mu \mathrm{g} / \mathrm{ml}$ of GEO lost their typical morphology, cells were shrunken and appeared smaller in size (Fig. 2). Furthermore, it was noticed that, cells treated with $60 \mu \mathrm{g} / \mathrm{ml}$ of GEO for $24 \mathrm{hr}$., appeared abnormal with a rounded shape and spaces between cells were increased compared to those in the control group. Additionally, some cells shrank with a ruptured membrane at a concentration of $100 \mu \mathrm{g} / \mathrm{ml}$ of GEO, suggesting apoptotic cell death. The proportion of abnormal and dead cells increased with increasing GEO concentrations.

\section{Mitochondrial Membrane Potential}

Mitochondrial membrane depolarization was detected using a fluorescent dye TMRE in MCF-7 cells treated with GEO. The cytofluorometric analysis of mitochondrial $\Delta \Psi \mathrm{m}$ is shown in Fig. 3a. The results presented in Fig. 3a and b had clearly shown that, GEO-induced apoptosis visualized by TMRE staining of MCF-7 cells treated with $10.12 \mu \mathrm{g} / \mathrm{ml}$ GEO $\left(\mathrm{IC}_{50}\right)$. The percent of MCF-7 stained cells was decreased sharply from $36.20 \%$ to 16.49 by $54.45 \%$ after treatment with GEO compared with the untreated cells (Fig. 3a) and cells appeared to contain a lower level of TMRE compared to control cells (Fig. 3b). Our findings suggest that, treatment of MCF-7 cells with GEO induces apoptosis because the cell population with relatively low TMRE staining became predominant in the samples exposed to GEO. Loss of mitochondrial membrane potential is indicative of apoptosis. This confirms that, GEO treatment caused more cells to undergo a reduction in mitochondrial membrane potential $(\Delta \Psi \mathrm{m})$ and the effect of GEO in inducing apoptosis in MCF-7 cells involves a decrease of mitochondrial membrane potential.

\section{DISCUSSION}

Cancer is the cause of more than 6 million deaths worldwide every year (Janakiraman and Johnson, 2016). More than 700,000 new cases of cancer occur in Asian countries and this number is expected to increase each year (Kimman et al., 2012). Breast cancer is the most common malignancy in women with nearly a half 


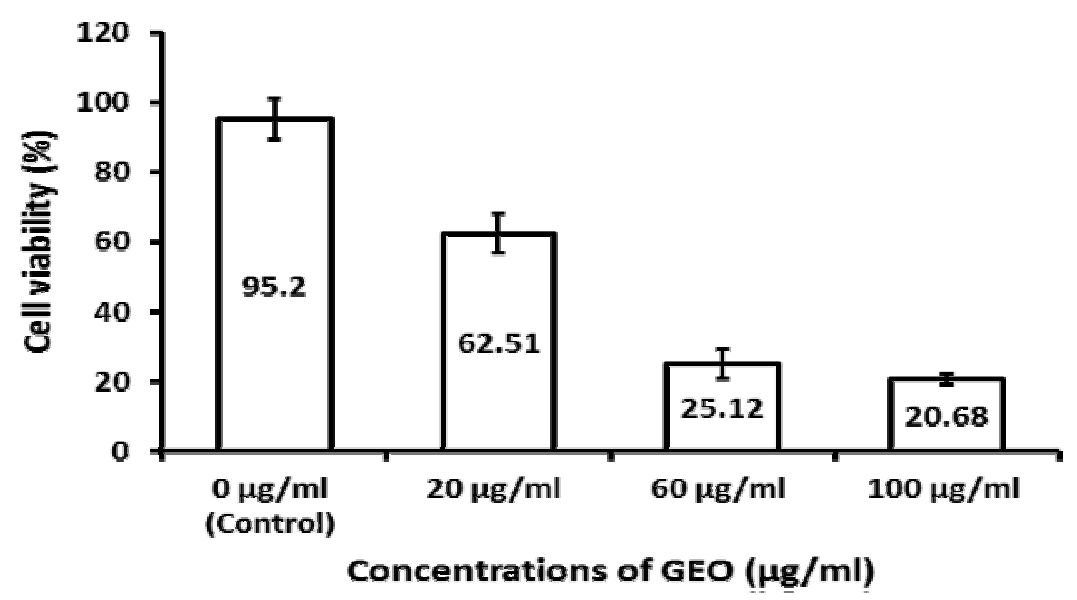

Fig. 1. Cell viability assessments using trypan blue assay following the exposure of various concentrations of ginger essential oil (GEO) for $24 \mathrm{hr}$., values are mean \pm SD of three replicates $(\mathbf{p}<0.05$ vs control)

Table 1. Cytotoxicity assessment of ginger essential oil (GEO) against human breast adenocarcinoma cells (MCF-7) as determined by the MTT assay

\begin{tabular}{lcc}
\hline Concentration of GEO $(\boldsymbol{\mu g} / \mathbf{m l})$ & MCF-7 (\%) inhibition \pm SD & IC $_{\mathbf{5 0}}$ \\
\hline $\mathbf{2 0}$ & $85.50 \pm 4.44$ & \\
$\mathbf{6 0}$ & $88.72 \pm 2.25$ & 10.12 \\
$\mathbf{1 0 0}$ & $78.67 \pm 3.22$ & \\
\hline
\end{tabular}

Results represented mean $\pm \mathrm{SD}, \mathrm{n}=3$

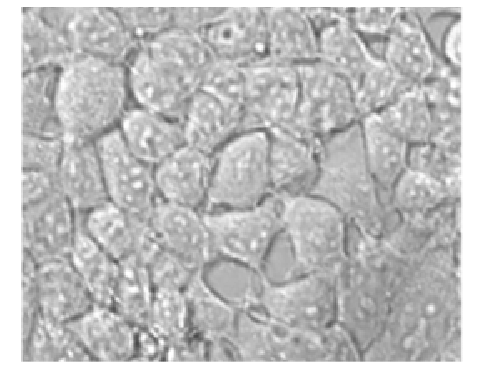

$0 \mu \mathrm{g} / \mathrm{ml}$ (Control)

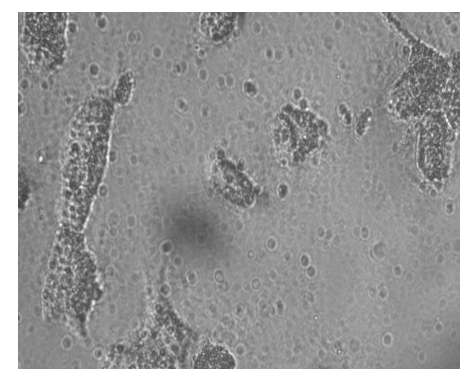

$60 \mu \mathrm{g} / \mathrm{ml}$

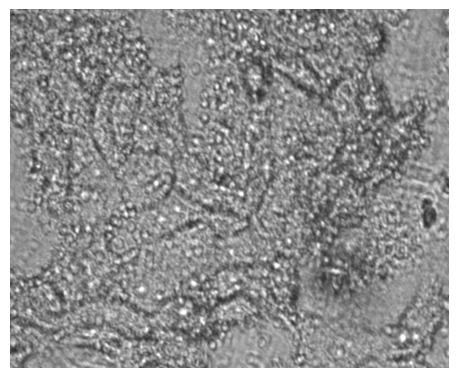

$20 \mu \mathrm{g} / \mathrm{ml}$

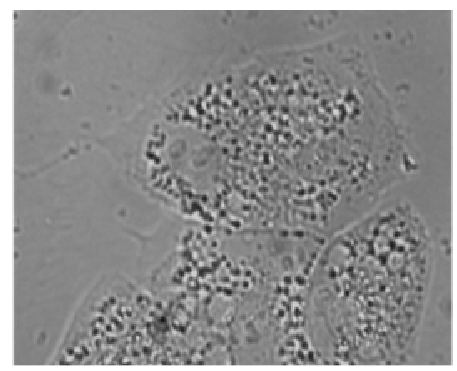

$100 \mu \mathrm{g} / \mathrm{ml}$

Fig. 2. Morphological alterations in MCF-7 cells exposed to various concentrations of ginger essential oil (GEO) for $24 \mathrm{hr}$, images were taken using a Zeiss Axio Vert. A1 microscope at $40 \mathrm{X}$ magnification 
(A)
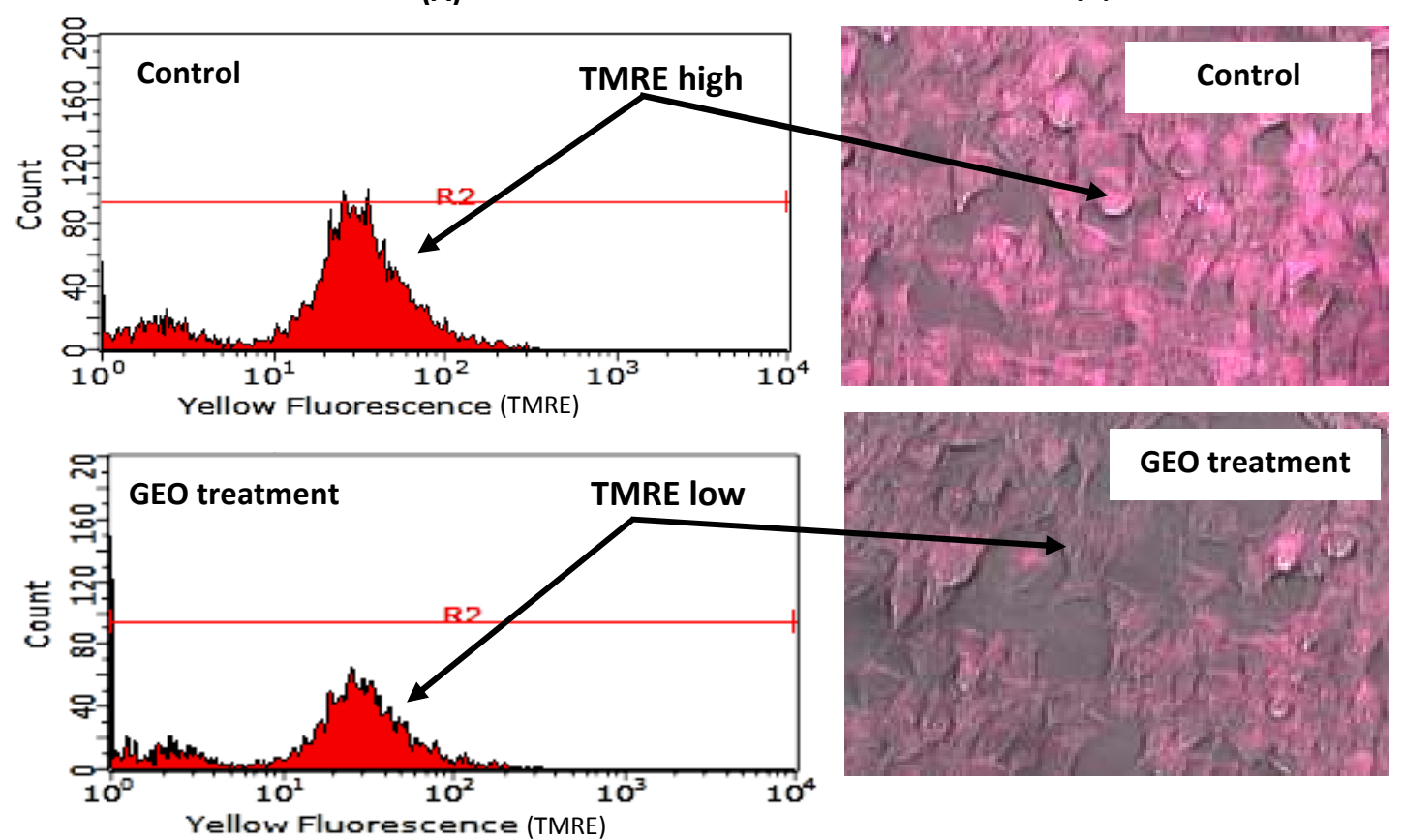

Fig. 3. Analysis of MCF-7 cells exposed to ginger essential oil (GEO) based on TMRE staining. (A): Cytofluorometric analysis of $\triangle \Psi \mathrm{m}$ in MCF-7 cells. Upper fluorescence histogram, of MCF-7 control cells, lower fluorescence histogram of MCF-7 cells treated with GEO. (B): Representative images of MCF-7 cells after staining with $200 \mathrm{nM}$ TMRE. Upper panel, TMRE ${ }^{\text {high }}$ in MCF-7 control cells; lower panel, TMRE ${ }^{\text {low }}$ in MCF-7 cells treated with GEO. Scale bar, $20 \mu \mathrm{m}$.

million deaths worldwide every year (Slaoui et al., 2014 ; Jahanafrooz et al., 2016). The rates of breast cancer vary worldwide being the highest in Europe, and they are increasing in Asian and Latin- American countries (Jung et al., 2009). In the Arab world, breast cancer incidence rates differ according to region and country. In Egypt, it is the most frequent cancer among females. In Lower, Middle, and Upper Egypt the pattern was dominated by the high frequency of breast cancer (Ibrahim et al., 2014). Surgery, chemotherapy, radiotherapy, and acupuncture point stimulation are used to treat cancer (Janakiraman and Johnson, 2016). These treatments may cause treatment-induced cancer pain and destroy the normal cells along with cancer cells; cancer cells can develop resistance to treatment through mutations (Wiseman and Spencer, 1998). Resistance to chemotherapeutic drugs is the main reason chemotherapy fails (Hutchins-Wolfbrandt and Mistry, 2011). So, there is still an urgent need for more effective cancer treatments. In the potential management of cancer, natural products derived from medicinal plants have gained significant recognition (Desai et al., 2008). Active components derived from plants are important sources of new drugs that are likely to lead to new and better treatments for breast cancer (Cragg and Newman, 2003).

Ginger as a one of medicinal plants has long been used in traditional medicine. (Al-Suhaibani and El-Morshedi, 2015). Much research has focused their attention to ginger as anti-cancer (Shukla and Singh, 2007), anti-oxidant (Jeyakumar et al., 1999) and anti-inflammatory (Park et al., 1998) agent. A number of recent studies have investigated the cytotoxicity of ginger plant extracts against MCF-7 human breast cancer cell line (Rahman et al., 2011; Park et al., 2014 ; Ray et al., 2015). 
Ginger essential oil consists of a very complex mixture of various classes of organic compounds which is responsible for its antioxidant activity (El-Baroty et al., 2010). It is a rich source of phenolic compounds such as shogaols, zingerone, gingerols and gengerdiols (Singh et al., 2008). Recently, studies had focused on the anticancer activities of ginger essential oil (Jeena et al., 2013 ; Jeena et al., 2015), but not extensively studied its cytotoxic effects and mode of action in breast cancer cell lines. Currently, the study of the cytotoxic activity of ginger essential oil against human breast adenocarcinoma cells has become more important in the field of anticancer drug development. Hence, the current investigation has evaluated the cytotoxic and apoptotic activities of GEO against MCF-7 human breast cancer cells. To the best of our knowledge, this is the first investigation, that exhibited high cytotoxic activity of GEO against MCF-7 human breast cancer cells and its mechanism of cell death using mitochondrial mechanism.

To determine the cytotoxic effect of GEO against MCF-7 cells, we first studied the effect of GEO on the cell viability. Cell viability assay showed that, GEO induced decrease in the percentage of MCF-7 viable cells in a concentration dependent manner. We further verified this cytotoxic effect of GEO by MTT assay. The MTT assay is based on the reduction of MTT by mitochondrial dehydrogenase by purple formazan product. The GEO were subjected to MTT cell proliferation assay. Increased growth inhibition was observed in MCF 7 cells in a concentration dependent manner by MTT assay. Maximum percentage cell inhibition was observed in MCF 7 cells at a concentration of $60 \mu \mathrm{g} / \mathrm{ml}$ of GEO. As the concentration increased, there was a decreased in cell growth inhibition. It was $78.67 \%$ growth inhibition at $100 \mu \mathrm{g} / \mathrm{ml}$. Furthermore, the $\mathrm{IC}_{50}$ value of GEO on MCF-7 cell line was 10.12 $\mu \mathrm{g} / \mathrm{ml}$. Moreover, morphological features in MCF-7 cancer cells after exposure to GEO indicated that, GEO has a substantial ability to alter the morphological and cytological structure of MCF-7 cancer cells.

A similar study conducted by Yuangang et al. (2010), conflicts the findings of our study. They found that, ginger essential oil exhibited the lowest cytotoxicity towards MCF-7 cells.
The percentage of cell viability was $81.85 \%$ in their study. The difference in the results of both studies may be due to the source of oil used in both studies, which could lead to differences in oil constituents. Nevertheless, we can be certain that, the inhibitory effect of GEO on breast cancer cells was recorded for the first time in our study using the mitochondrial observation.

To describe the cell death mechanism induced by GEO, we used TMRE dye as fluorescent probes to monitor the membrane potential of mitochondria. TMRE is a positivelycharged dye that use to label active mitochondria (Christensen et al., 2013).

Determination of mitochondrial membrane potential $(\Delta \Psi \mathrm{m})$ is widely used for characterization of cellular metabolism, viability, and apoptosis. The loss of mitochondrial membrane potential $(\Delta \Psi \mathrm{m})$ is a hallmark of apoptosis (Ahamad et al., 2014). Apoptosis (programmed cell death) is a normal process that occurs during development of cell. The process of apoptosis in case of cancer is uncontrolled. It is reported that, many chemotherapeutic agents exert their antitumor effects by inducing apoptosis in cancer cells (Kamesaki, 1998).

In the present study, we had shown that, GEO was able to induce apoptosis in MCF-7 cells. It has been observed that, there is a reduction in mitochondrial membrane potential $(\Delta \Psi \mathrm{m})$ in MCF-7 cells treated with GEO, compared to those in the control group. The effect of GEO in inducing apoptosis in MCF-7 cells involves a decrease of mitochondrial membrane potential.

In conclusion, according to the results from current study it seems that, ginger essential oil may induce apoptosis and reduces cell viability in MCF-7 human breast adenocarcinoma cells. In addition, there is a growing evidence that ginger essential oil had higher anticancer activity against breast cancer. Therefore, essential oil derived from ginger has great potential to be used in the field of anticancer drugs and could be employed in the treatment of cancerous diseases.

\section{Conflict of Interest}

The authors declare that they have no conflict of interest. 


\section{Funding}

This research was supported by the subsidy of the Russian and Egyptian Governments to support the Program of Competitive Growth of Kazan Federal University and Minia University.

\section{Acknowledgement}

We are grateful to Timur Abdullin and Oksana Bondar, Kazan federal university for technical assistance.

\section{REFERENCES}

Abd El-Rahman, A.A., S.M.A. El-Shafei, E.V. Ivanova, A.N. Fattakhova, A.N. Pankova and M.A. El-Shafei (2014). Cytotoxicity of Trichoderma spp. cultural filtrate against human cervical and breast cancer cell lines. Asian Pac. J. Cancer Prev., 15: 7229-7234.

ACS (2014). American Cancer Society. Breast Cancer. Atlanta, Ga: Ame. Cancer Soc., 1-127.

Ahamad, M.S., S. Siddiqui, A. Jafri, S. Ahmad and M. Afzal (2014). Induction of apoptosis and antiproliferative activity of Naringenin in human epidermoid carcinoma cell through ROS generation and cell cycle arrest. PLoS One, 9: 1-8.

Akao, M., Y. Teshima and E. Marban (2002). Antiapoptotic effect of nicorandil mediated by mitochondrial ATP-sensitive potassium channels in cultured cardiac myocytes. J. Ame. Coll. Cardiol., 40: 803-810.

Al-Suhaibani, E.S. and N.A. El-Morshedi (2015). Ginger oil effect as apoptosis inducer in colorectal (caco-2) cancer cell line. Int. J. Advan. Res., 3: 530-535.

Chazotte, B. (2011). Labeling mitochondria with TMRM or TMRE. Cold Spring Harb Protoc., 7: 895-897.

Choudhury, D., A. Das, A. Bhattacharya and G. Chakrabarti (2010). Aqueous extract of ginger shows antiproliferative activity through disruption of microtubule network of cancer cells. Food Chem. Toxicol., 48: 28722880 .

Christensen, M.E., E.S. Jansen, W. Sanchez and N.J. Waterhouse (2013). Flow cytometry based assays for the measurement of apoptosis-associated mitochondrial membrane depolarisation and cytochrome $\mathrm{c}$ release. Methods, 61: 138-145.

Coisin, M., I. Burzo, M. Stefan, E. Rosenhech and M.M. Zamfirache (2012). Chemical composition and antibacterial activity of essential oils of three Salvia species, widespread in eastern Romania. Biol Veget., 58: 51-58.

Cragg, G.M. and D.J. Newman (2003). Plants as a source of anti-cancer and anti-HIV agents. Ann. Appl. Biol., 143: 127-133.

Dagli, N., R. Dagli, R.S. Mahmoud and K. Baroudi (2015). Essential oils, their therapeutic properties, and implication in dentistry: A Review. J. Int. Soc. Prev. Comm. Dent., 5: 335-340.

Desai, A.G., G.N. Qazi, R.K. Ganju, M. ElTamer, J. Singh and A.K. Saxena (2008). Medicinal plants and cancer chemoprevention. Curr. Drug. Metab., 9: 581-591.

Dugasani, S., M.R. Pichika, V.D. Nadarajah, M.K. Balijepalli, S. Tandra and N. Korlakunta (2010). Comparative antioxidant and anti-inflammatory effects of [6]gingerol, [8]-gingerol, [10]-gingerol and [6]shogaol. J. Ethnopharmacol., 127: 515-520.

El-Baroty, G.S., H.H. Abd El-Baky, R.S. Farag and M.A. Saleh (2010). Characterization of antioxidant and antimicrobial compounds of cinnamon and ginger essential oils. Afr. J. Biochem. Res., 4:167-174.

Farshori, N.N., E.S. Al-Sheddi, M.M. Al-Oqail, J. Musarrat, A.A. Al-Khedhairy and M.A. Siddiqui (2013). Anticancer activity of Petroselinum sativum seed extracts on MCF7 human breast cancer cells. Asian Pac. J. Cancer Prev., 14: 5719-5723.

Hakim, L., E. Alias, S. Makpol, W.Z. Ngah, N.A. Morad and Y.A. Yusof (2014). Gelam honey and ginger potentiate the anticancer effect of 5-FU against HCT 116 colorectal cancer cells. Asian Pac. J. Cancer Prev., 15: 4651 - 4657.

Hamedeyazdan, S., F. Fathiazad, S. Sharifi and H. Nazemiyeh (2012). Antiproliferative activity of Marrubium persicum extract in the MCF-7 human breast cancer cell line. Asian Pac J. Cancer Prev., 13: 5843-5848. 
Hutchins-Wolfbrandt, A. and A.M. Mistry (2011). Dietary turmeric potentially reduces the risk of cancer. Asian Pac. J. Cancer Prev., 12: 3169-3173.

Ibrahim, A.S., H.M. Khaled, N.N.H Mikhail, H. Baraka and H. Kamel (2014). Cancer incidence in Egypt: Results of the national population-based cancer registry program. J. Cancer Epidemiol., 2014:1-18.

Jahanafrooz, Z., N. Motameh and B. Bakhshandeh (2016). Comparative evaluation of silibinin effects on cell cycling and apoptosis in human breast cancer MCF-7 and T47D cell lines. Asian Pac. J. Cancer Prev., 17 : 26612665.

Janakiraman, N. and M. Johnson (2016). Ethanol extracts of selected Cyathea Species decreased cell viability and inhibited growth in MCF 7 cell line cultures. J. Acupunct Meridian Stud., 9: 151-155.

Jeena, K., V.B. Liju and R. Kuttan (2013). Antioxidant, anti-inflammatory and antinociceptive activities of essential oil from ginger. Ind. J. Physiol. Pharmacol., 57: 5162.

Jeena, K., V.B. Liju and R. Kuttan (2015). Antitumor and cytotoxic activity of ginger essential oil (Zingiber officinale Rosc.). Int. J. Pharm. Sci., 7: 341-344.

Jeena, K., V.B. Liju, V. Ramanath and R. Kuttan (2016). Protection against whole body $\gamma$-irradiation induced oxidative stress and clastogenic damage in mice by ginger essential oil. Asian Pac. J. Cancer Prev., 17: 1325-1332.

Jeyakumar, S.M., N. Nalini and V.P. Menon (1999). Antioxidant activity of ginger (Zingiber officinale) in rats fed a high fat diet. Med Sci Res., 27: 341- 344.

Jolad, S.D., R.C. Lantz, A.M. Solyom, G.J. Chen and R.B. Bates (2004). Timmermann BN. Fresh organically grown ginger (Zingiber officinale): composition and effects on LPS-induced PGE2 production. Phytochem., 65: 1937-1954.

Jung, K.W., Y.J. Won, S. Park, H-J. Kong, J. Sung and H-R. Shin (2009). Cancer statistics in Korea: incidence, mortality and survival in 2005. J. Korean. Med. Sci., 24: 995-1003.

Kamesaki, H. (1998). Mechanisms involved in chemotherapy-induced apoptosis and their implications in cancer chemotherapy. Int. J. Hematol., 68: 29 - 43.

Karimi, N. and V.D. Roshan (2013). Change in adiponectin and oxidative stress after modifiable lifestyle interventions in breast cancer cases. Asian Pac. J. Cancer Prev., 14: 2845-2850.

Kim, J.S., S.I. Lee, H.W. Park, J.H. Yang, T.Y. Shin and Y.C. Kim (2008). Cytotoxic components from the dried rhizomes of Zingiber officinale Rosc. Arch. Pharmacol Res., 31: 415-418.

Kimman, M., R. Norman, S. Jan, D. Kingston and M. Woodward (2012). The burden of cancer in member countries of the association of Southeast Asian nations (ASEAN). Asian Pac. J. Cancer Prev., 13: 411-420.

Kubra, I.R. and LJ. Rao (2012). An impression on current developments in the technology, chemistry, and biological activities of ginger (Zingiber officinale Rosc.). Crit. Rev. Food Sci. Nut., 52: 651-688.

Ling, H., H. Yang, S.H. Tan, W.K. Chui and E.H. Chew (2010). 6-Shogaol, an active constituent of ginger, inhibits breast cancer cell invasion by reducing matrix metalloproteinase-9 expression via blockade of nuclear factor- $\mathrm{kB}$ activation. Br. J. Pharm., 161: 1763-1777.

Mariadoss, A.V., S. Kathiresan, R. Muthusamy and S .Kathiresan (2013). Protective effects of [6]-paradol on histological lesions and Immunohistochemical gene expression in DMBA induced hamster buccal pouch carcinogenesis. Asian Pac. J. Cancer Prev., 14: 3123-3129.

Mosmann, T. (1983). Rapid colorimetric assay for cellular growth and survival: application to proliferation and cytotoxicity assays. J. Immunol. Meth., 65 : 55-63.

Park, G.H., J.H. Park, H.M. Song, M.K. Eo hj, Kim and J.W. Lee (2014). Anti-cancer 
activity of ginger (Zingiber officinale) leaf through the expression of activating transcription factor 3 in human colorectal cancer cells. BMC Complement Altern Med., 14: 408-416.

Park, K.K., K.S. Chun, S.S. Lee and Y.J. Surh (1998). Inhibitory effect of [6]-gingerol, a major pungent principle of ginger, on phorbol ester-induced inflammation, epidermal ornithine decarboxylase activity and skin tumor promotion in ICR mice. Cancer Lett., 129: 139 - 144.

Patel, S., N. Gheewala, A. Suthar and A. Shah (2009). In vitro cytotoxicity activity of Solanum nigrum extract against hela cell line and vero cell line. Int. J. Pharm. Pharmaceuti Sci., 1: 38-46.

Plengsuriyakarn, T., V. Viyanant, V. Eursitthichai, S. Tesana, W. Chaijaroenkul, A. Itharat (2012). Cytotoxicity, toxicity, and anticancer activity of Zingiber officinale Rosc. against cholangiocarcinoma. Asian Pac. J. Cancer Prev., 13: 4597-4606.

Rahman, S., F. Salehin and A. Iqbal (2011). In vitro antioxidant and anticancer activity of young Zingiber officinale against human breast carcinoma cell lines. BMC Complement Altern Med., 11: 76-83.

Ray, A., S. Vasudevan and S. Sengupta (2015). 6-Shogaol inhibits breast cancer cells and stem cell like spheroids by modulation of notch signaling pathway and induction of autophagic cell death. PLoS One, 10: 1-22.

Richie, R.C. and J.O. Swanson (2003). Breast cancer: A review of the literature. J. Insur. Med., 35: 85-101.

Sang, S., J. Hong, H. Wu, J. Liu, C.S. Yang and H-H. Pan (2009). Increased growth inhibitory effects on human cancer cells and antiinflammatory potency of shogaols from Zingiber officinale relative to gingerols. J. Agric. Food Chem., 57: 10645-10650.

Sasidharan, I. and M.A. Nirmala (2010). Comparative chemical composition and antimicrobial activity fresh and dry ginger oils (Zigiber officinale Rosc.). Int. J. Cur. Pharm. Res., 2: 40-43.

Shukla, Y. and M. Singh (2007). Cancer preventive properties of ginger: A brief review. Food Chem. Toxicol., 45: 683-690.
Siddiqui, M.A., G. Singh, M.P. Kashyap, V.K. Khanna, S. Yadav and D. Chandra (2008). Influence of cytotoxic doses of 4hydroxynonenal on selected neurotransmitter receptors in PC-12 cells. Toxicol In vitro, 22: 1681-1688.

Simstein, R., M. Burow, A. Parker, C. Weldon and B. Beckman (2003). Apoptosis, chemoresistance, and breast cancer: insights from the MCF-7 cell model system. Exp Biol Med., 228: 995-1003.

Singh, G., I.S. Kapoor, P. Singh, C.S. de Heluani, M.P. de Lampasona and C.A. Catalan (2008). Chemistry, antioxidant and antimicrobial investigation on essential oil and oleoresine of Zingiber officinale. Food Chem. Toxicol., 46: 3295-3302.

Slaoui, M., R. Razine, A. Ibrahimi, M. Attaleb, M.E. Mzibri and M. Amrani (2014). Breast cancer in Morocco: A literature review. Asian. Pac. J. Cancer. Prev., 15: 1067- 1074.

Soule, H.D., J. Vazquez, A. Long, S. Albert and M. Brennan (1973). A human cell line from a pleural effusion derived from a breast carcinoma. J. Nat. Cancer Inst., 51 : 1409 1416.

Wee, L.H., N.A. Morad, G.J. Aan, S. Makpol, W.Z. Ngah and M.YA. Yusof (2015). Mechanism of chemoprevention against colon cancer cells using combined gelam honey and ginger extract via mTOR and Wnt/ $\beta$-catenin Pathways. Asian. Pac. J. Cancer Prev., 16: 6549-6556.

Weng, .CH., .CF. Wu, H.W. Huang and C.T. Ho (2010). Anti-invasion effects of 6-shogaol and 6 gingerol, two active components in ginger, on human hepatocarcinoma cells. Molecular Nut. Food Res., 54: 1618-1627.

Wiseman, L.R. and C.M. Spencer (1998). Paclitaxel: An update of its use in the treatment of metastatic breast cancer and ovarian and other gynaecological cancers. Drugs Aging., 12: 305-334.

Yuangang, Z.U., Y.U. Huimin and L.U. Liang (2010). Activities of ten essential oils towards propionibacterium acnes and $\mathrm{PC}-3$, A-549 and MCF-7 cancer cells. Molecules, 15: $3200-3210$. 
زيت الزنجبيل الطيار يثبط النمو ويحدث موت الخلايا المبرمج في خلايا سرطان الثدي JCF-7

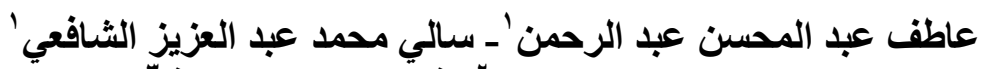

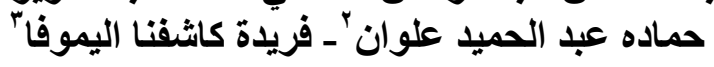

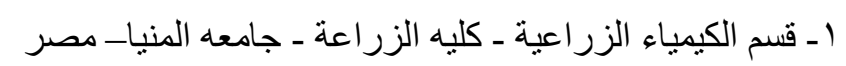

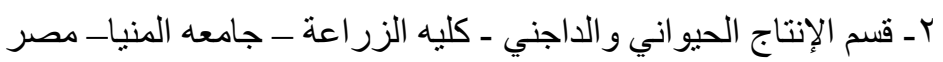

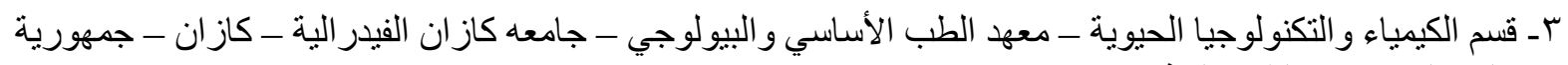
تتارستان - روسيا الاتحادية

عرف نبات الزنجبيل كو احد من أهم النباتات الطبية وكأحد المو اد الغذائية الغنية بالمركبات الكيميائية، ولقد استخدم لعده

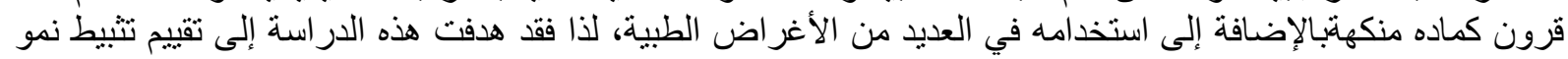

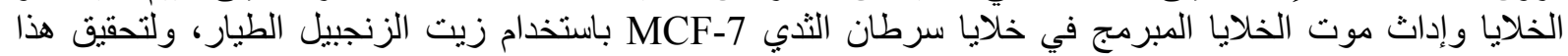

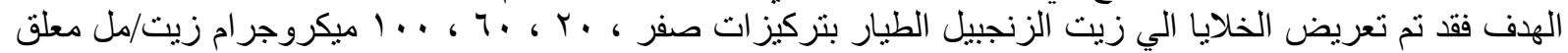

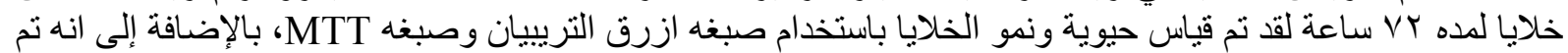

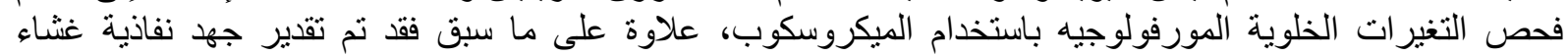

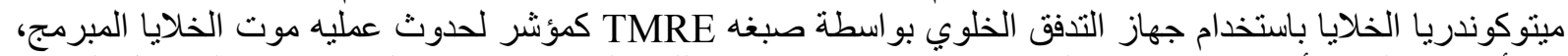

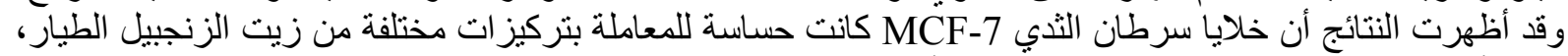

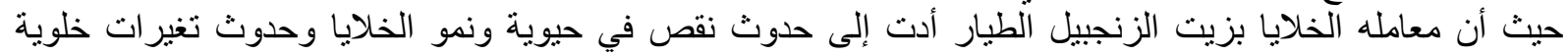

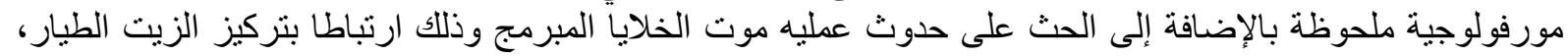

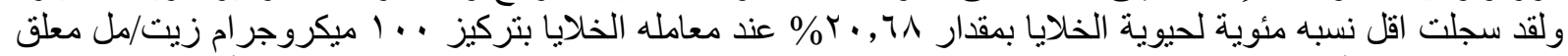

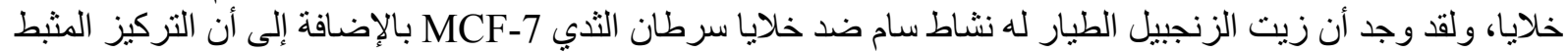

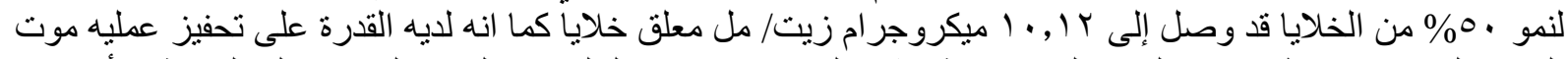

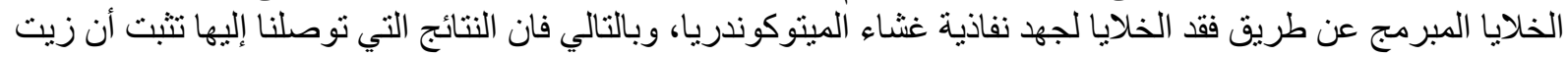

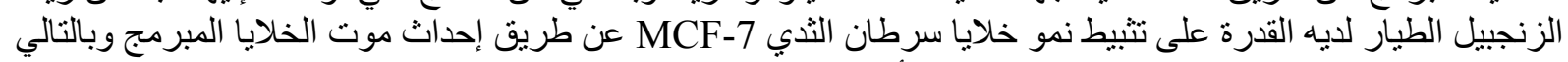

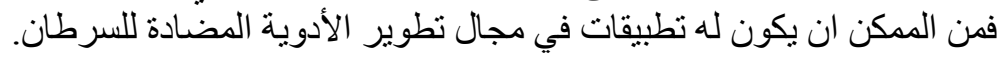

